Ann. Génét. Sél. anim., I974, 6 (4), 493-496.

NOTE

\title{
AGE INFLUENCED CATTLE SERUM ANTIGEN DETECTED BY AUTOANTIBODIES
}

\author{
D. IANNELLI, P. MASINA and T. M. BETTINI \\ Istituto di Produzione animale, \\ Facoltá Agraria, Portici, \\ 80055 Naples (Italy)
}

\section{SUMMARY}

The serum of an Italian Friesian bull (Rocket-A $b$ ) contained autoantibodies specific for a serum antigen $\left(\mathrm{R}^{\mathrm{A} g}\right)$ whose expression seems age-influenced.

The present article is a development of a short communication presented at the E. A. A. P. meeting of Verona (1972) by IANNelli et al. (1973).

While typing Italian Friesian cattle sera for an allotipic specificity by double diffusion, a precipitin line was observed between two peripheral wells containing normal sera. The test was performed using $26 \times 76 \mathrm{~mm}$ microscope slides and, as supporting medium, I p. Ioo Difco Bacto Agar (Difco Laboratories, U. S. A.) in Hemagglutination buffer (Baltimore Biological Laboratory, U.S. A.). The diameter of the wells was $2 \mathrm{~mm}$ and the distance between the circumference of the central well and of the four peripheral ones $2,5 \mathrm{~mm}$.

Serum samples and antiserum before being tested were concentrated three times by pervaporation (MOoRE et al., I968). Four microliters of antiserum were placed in the central well and four microliters of each of the serum samples to be tested in the outer wells. After one hour the central well was refilled with additional four microliters of antiserum.

A precipitin line appeared between the sera of Rocket-A $b$ (a bull) and 1035 (a calf). At the time samples were collected, the former was five years and the latter three months old. To distinguish which of these two sera contained the antibodies, both were tested against a panel of fourty normal sera. The calf I035 showed no reaction, whereas Rocket-A $b$ reacted with three animals. Obviously the latter was the source of antibodies. Rocket- $\mathrm{A} b$, in spite of great caution to avoid its freezing and thawing as much as possible, deteriorated very rapidly. The incorporation of polyethylene glycol (m. w. 6ooo, Serva, West Germany) into the agar (Eby et al., 1973; Stone, 1973) did not help. By the time the antiserum was no longer reactive, only the sera of 270 animals (of 
both-sexes) had been tested and 23 of them resulted positive. The possibility to characterize the antigen by immunoelectrophoresis was precluded by the sudden deterioration of the antiserum. Incidentally, the same phenomenon - i.e. rapid destruction of antibodies - had been observed also with water-buffalo anti-allotype antibodies formed at the early stages of iso-immunization. No evidence of transfusion, illness, vaccination was found, nor of any other peculiarity that could account for the presence of antibodies in Rocket- $\mathrm{A} b$ and/or of the antigen in the 23 positive animals.

On the other hand, precipitin lines between cattle normal sera had already been observed in similar circumstances $(i . e$. while searching for allotypic specificities), resulting from autoantibodies against cattle haemoglobin. Rocket-A $b$ was therefore tested against a serum sample of Rocket (Rocket-Ag) collected two years previously and fortunately still available. A precipitin line developed between the well containing the two samples of Rocket, thus suggesting the presence in Rocket- $\mathrm{A} b$ of autoantibodies $\left(\mathrm{R}^{\mathrm{A} b}\right)$ against an antigen $\left(\mathrm{R}^{\mathrm{A} g}\right)$ present in Rocket- $\mathrm{A} g$.

Autoantibodies of known specificities (red cells in particular) have been noted many times (RACE and SANGer, 1962).

Absorption of Rocket-A $b$ by the intra-basin technique (four microliters of absorbing serum and, one hour later, an equal amount of antiserum) with Rocket- $\mathrm{A} g$ and with three different positive animals, used individually, inhibited the reaction for every other positive animal. Coalescence between adjacent precipitin lines was observed sometimes (fig. $x$ ). Analysis of family data disclosed positive offspring from negative parents; positive offspring from positive $\times$ negative parents were much less than the expected ratio of $5^{\circ} \mathrm{p}$. 100 and finally no positive $\times$ positive matings were found. These data did not agree with the hypothesis of a simple mechanism of inheritance of the antigen $\mathrm{R}^{\mathrm{A} g}$. With the exception of two bulls (Rocket-Ag mentioned above and Eglantier), it was observed that positive animals all had an age varying from a few days to seven months as a common characteristic. Passive transmission of the antigen from mother to newborn was excluded as a possible explanation, since all mothers turned out negative. The possibility was then considered that the antigen expression required not only the proper gene but also a proper age of the animal.

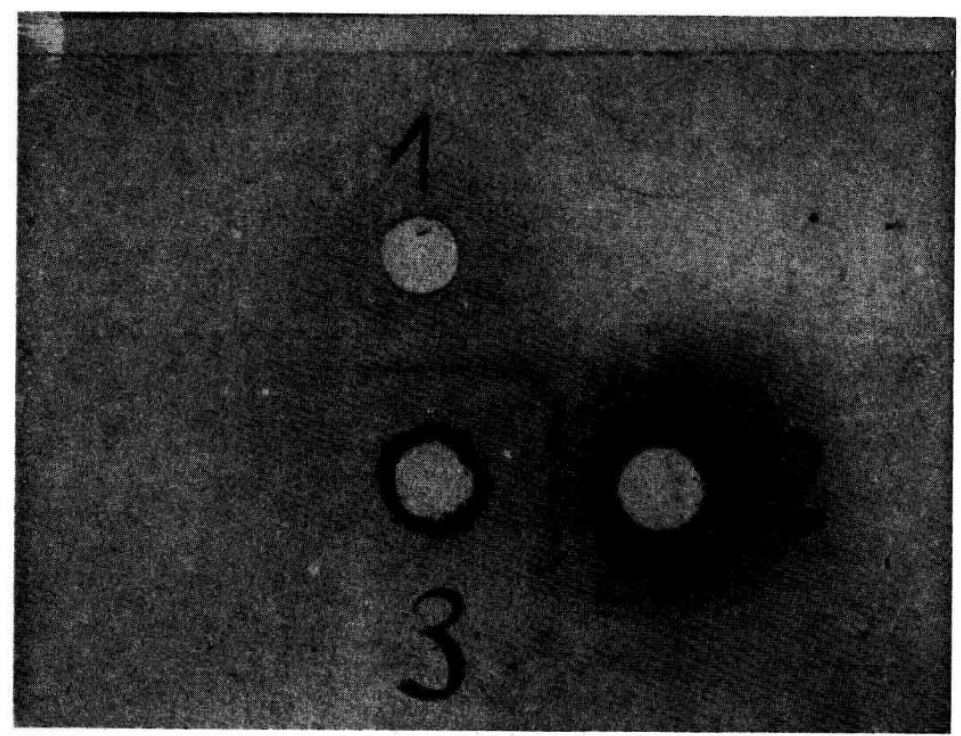

FIG. I. - Ouchterlony plate showing the precipitin reactions of Rocket-Ab (well 3) with Rocket-Ag (well I) and Eglantier (well 2)

Amidoschwartz staining 
This hypothesis explained how positive offspring could emerge from negative parents : either one or both the parents possessed the specific gene but not the proper age to express it. The same explanation accounted for the mentioned lack of positive $\times$ positive matings. The discrepancy between the observed and the expected ratio of positive and negative offspring from positive $\times$ negative matings was also eliminated when, according with the suggested mechanism, only offspring with the proper age were considered (table I). Further, samples collected from five animals at the age of $3,6,5,4$ and 4 months were positive while those collected from the same animals respectively at the age of. 10, I2, I 5, 23 and 21 months all tested at the same time resulted negative. This is what one would expect on the basis of the proposed hypothesis. The tentative suggestion put forward to account for the data given in the table is therefore that the antigen $\mathrm{R}^{\mathrm{A} g}$ is presumably controlled by an age-influenced dominant mendelian gene. However, it remains unexplained why Rocket-Ag and Eglantier were positive (despite their being definitely older than 7 months) but no explanation is available at present on this point.

TABLE I

Inheritance of $R A \mathrm{~g}$ Antigen. Reported only offspring up to seven months old

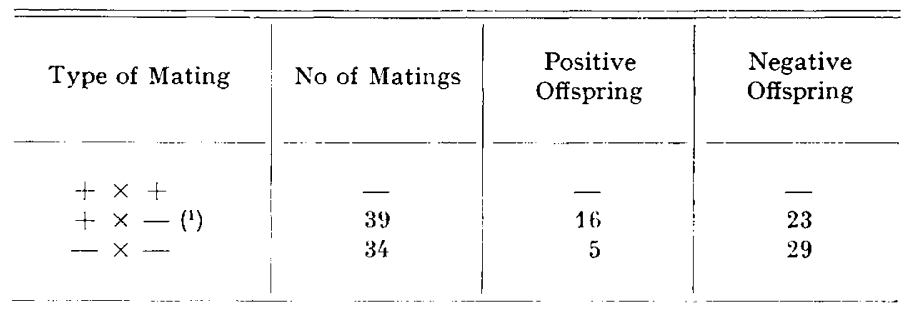

(1) Rocket-Ag and Eglantier.

The mechanism through which antigen synthesis is switched off at a certain age is also unknown; the possibility should be considered that it is induced by hormone $(s)$, analogously to the hormone-influenced serum protein (HIP) in chicken (DAvID, 1970), the sex-limited protein (Slp) antigen of the mouse (PASSMORE and SHREFFLR, 1970), the female specific protein in Leucophaea maderae (ENGelmanN, 1969).

Whether it is only a chance that two exceptions were found among twenty bulls but none among more than one hundred females older than seven months, whether both sexes are equally likely to form autoantibodies is unanswered question at present. Further studies to provide answer to the above questions and to characterize the chemical nature of the $\mathrm{R}^{\mathrm{A} g}$ antigen depend on the possibility of picking up a duplicate of Rocket-A $b$.

Rę̧u pour publication en septembre 1974.

\section{ACKNOWLEGMENTS}

One of the authors (D.I.) wishes to thank Dr W. H. STone for his helpful suggestions during the preparation of this manuscript. The work was supported by the Consiglio Nazionale delle Ricerche (Italy). 


\section{RÉSUMÉ \\ ANTIGÈNE SÉRIQUE BOVIN DÉTECTÉ PAR AUTOANTICORPS ET INFLUENCÉ PAR L'ÂGE}

Le sérum d'un taureau de race Frisonne italienne (Rocket $\mathrm{A} b$ ) contenait des autoanticorps vis-à-vis d'un antigène sérique $\left(\mathrm{R}^{\mathrm{A} g}\right)$ dont l'expression semble influencée par l'âge.

\section{REFERENCES}

Eby C. W., Kim B.S., Dray S., Young-Cooper G. O., Mage G., I973. Detection of the e r4 and e 15 rabbit allotypic specificities by immunodiffusion in peg agar. Immunochemistry, 10, 4I7-4I8.

DAvid C. S., I970. Hormone-influenced serum protein (HIP) : antiprotein system in the chicken. Imm., 106, IIO4-IIII.

ENGElmanN F., I969. Female specific protein : biosynthesis controlled by corpus allatum in Leucophaea maderae. Science, 165, 407-409.

Iannelli D., Alvino C. G., Bettini T. M., 1973. Inheritance of an age-influenced cattle serum antigen detected by autoantibodies. Ann. Génét. Sel. anim., 5, 285-000.

Moore B. P. L., Humphreys P., Lovett-Mosely C. A., ig68. Serological and immunological methods, p. 258-260. Canadian Red Cross Society, Toronto.

Race R. R., SANGer R., r962. Blood groups in man, p. 399-40r. Blackwell Scientific Publications, Oxford.

Stone W. H., r973. (Personal Communication). 